\title{
Physiological, biochemical, and ultrastructural responses of the green macroalga Urospora penicilliformis from Arctic Spitsbergen to UV radiation
}

\author{
Michael Y. Roleda • Ursula Lütz-Meindl • \\ Christian Wiencke • Cornelius Lütz
}

Received: 11 December 2008 / Accepted: 18 February 2009/Published online: 19 March 2009

(C) Springer-Verlag 2009

\begin{abstract}
Exposure of the filamentous turf green alga Urospora penicilliformis to ambient and artificial ultraviolet radiation (UVR) revealed a considerable resilient species. This explains the ability of this alga to thrive in the middleupper intertidal zones of the Arctic sea where it is periodically exposed to environmental extremes. A transient UVR effect on photosynthesis under photosynthetically active radiation (PAR) + UV-A and PAR + UV-A + UV-B was found, but dynamic recovery of photoinhibition was observed immediately after reduction of the photon fluence rate of PAR in the absence or presence of background UVR under laboratory and natural solar radiation, respectively. Chlorophylls, carotenoids, and xanthophyll cycle pigments (violaxanthin, antheraxanthin, and zeaxanthin) concentrations were not significantly different between freshly
\end{abstract}

\author{
M. Y. Roleda $(\bowtie)$ \\ Institute for Polar Ecology, University of Kiel, \\ Wischhofstr. 1-3, Bldg. 12, \\ 24148 Kiel, Germany \\ e-mail:mroleda@ipoe.uni-kiel.de \\ U. Lütz-Meindl \\ Plant Physiology Division, Cell Biology Department, \\ University of Salzburg, \\ Hellbrunnerstrasse 34, \\ 5020 Salzburg, Austria \\ C. Wiencke \\ Section Functional Ecology, Department Seaweed Biology, \\ Alfred Wegener Institute for Polar and Marine Research, \\ Am Handelshafen 12, \\ 27570 Bremerhaven, Germany \\ C. Lütz \\ Department Physiology and Cell Physiology of Alpine Plants, \\ Institute of Botany, University of Innsbruck, \\ Sternwartestrasse 15 , \\ 6020 Innsbruck, Austria
}

collected samples and filaments exposed to additional laboratory radiation treatment. The ultrastructure of the $U$. penicilliformis gametophytes showed that the cells are well adapted to UVR. No significant ultrastructural alterations were observed in filaments exposed to different spectral irradiance in the laboratory compared to in situ acclimated specimen. The antioxidant $\alpha$-tocopherol was detected in minute quantity while the search for flavonoid-like compounds was negative. Other UV screening strategies or certain genetically fixed physiological protective mechanism could be operating in this species responsible for their occurrence in higher shoreline and ecological success. Further molecular and biochemical studies are needed to elucidate the stress resistance in this turf alga. There is an indication that the extremely thick cell wall of $U$. penicilliformis gametophytes covered with mucilage sheath and dense layer of mineral depositions may provide a shield against unfavorable environmental conditions in general and against UVR in particular.

Keywords $\alpha$-Tocopherol · Carotenoids . Cell wall mineral deposition $\cdot$ Chlorophyll $\cdot P-E$ curve $\cdot$ Photosynthesis .

Ultrastructure $\cdot$ Xanthophyll cycle pigments

\section{Introduction}

Solar radiation plays an important role in structuring macroalgal communities in rocky shore ecosystems. Biota inhabiting the supra- and eulittoral zones are mostly green macroalgae periodically exposed to variable physicochemical gradients including desiccation, radiation, temperature, nutrient, and osmotic stress factors. Despite their exposure to environmental extremes, turf algae form a conspicuous component of the intertidal ecosystem; the 
ecological enigma of their resilience and survival strategies, however, remains to be unraveled. Disruptive stress-tolerant algae (cf. Davison and Pearson 1996 for the definition of disruptive stress) may exhibit unique responses when exposed to multiple stress factors. For example, under desiccation, certain cyanobacteria exposed to photoinhibiting irradiance are able to deactivate photosystem II (PSII) activity and dissipate absorbed light energy to avoid photodamage (Fukuda et. al. 2008) while access to phosphorous renders summer bloom-forming cyanobacteria less susceptible to ultraviolet radiation (UVR; e.g. Roleda et al. 2008). On the other hand, desiccation can also increase thermotolerance in intertidal marine macroalgae (Hunt and Denny 2008, and references therein).

The seasonal depletion of stratospheric ozone concentration over the polar regions initiated numerous research efforts to elucidate the biological consequences of the related increase in UV-B radiation reaching the biosphere. Even under non-depleted ozone conditions, UV-B still presents potential negative impacts to photosynthetic organisms. UV-sensitive molecules such as DNA, proteins, and pigments can be damaged upon UV exposure. As a consequence, several physiological and metabolic processes such as photosynthesis, respiration, growth, and reproduction will be compromised (Caldwell et al. 1998; Björn et al. 1999; Holzinger and Lütz 2006; Roleda et al. 2007). Under enhanced UVR, cellular development and ultrastructural integrity may also be at risk depending on the UV tolerance of the species (e.g., Meindl and Lütz 1996; Lütz et al. 1997; Poppe et al. 2002, 2003; Holzinger et al. 2006; Steinhoff et al. 2008).

Compared to brown and red macroalgae, information on the UV-protective mechanisms in green macroalgae is limited. Excretion of 3,6,7-trihydroxycoumarin, a group of UV-absorbing compounds with maximum absorption at 332-348 $\mathrm{nm}$ is reported in the Mediterranean siphonous green alga Dasycladus vermicularis (Scopoli) Krasser (class Ulvophyceae) exposed to high irradiance and temperature (Pérez-Rodríguez et al. 2001). A presumptive UV-absorbing compound with strong absorption below $300 \mathrm{~nm}$ was detected in methanol extracts of Ulva pertusa Kjellman (Ulvophyceae; Han and Han 2005). Another UVabsorbing compound identified as 324-nm mycosporinelike amino acid (MAA) was described in Prasiola crispa (Lightfoot) Kützing and occurs only in numerous green algal members of the Trebouxiophyceae (Karsten et al. $2005,2007)$. The absence of this compound in members of the Ulvophyceae and Chlorophyceae suggests a phylogenetic pattern in MAA synthesis.

A study on UV-induced changes in gene expression of the green macroalga Acrosiphonia sp. (Ulvophyceae) found an up-regulation for chalcon synthase, a key enzyme involved in flavonoid synthesis, after exposure to enhanced
UV-B radiation (Kremb 2007) pointing to the possibility that flavonoids may be involved in the protection against UVR in green algae. Flavonoids are products of phenolic metabolism which occur, in gymnosperms and angiosperms but seem to be missing in algae (Jordan 2002). Induction and synthesis of flavonoids in terrestrial plants by UVR is well reported. Simple phenolics (phenylpropanes), however, occur in higher and in lower plants and act as UV filters (Rozema et al. 1997).

In this study, we investigated the physiological, biochemical, and ultrastructural response of Urospora penicilliformis (Roth) J. E. Areschoug to UVR. U. penicilliformis is distributed mostly in cold temperate waters of both Hemispheres, and also in Arctic and Antarctic seas (Bischoff and Wiencke 1995). The species inhabits hard substrates in the middle-upper intertidal and the splash zone and is daily exposed to extreme changes in environmental conditions. In the present study, we examined the photosynthetic performance, pigment composition, and ultrastructure of filaments exposed under ambient solar radiation and under different spectral irradiance treatment in the laboratory. It was analyzed if the resilience and occurrence of turf algae in shallow water and high light-exposed sites could be ascribed to the presence of a UV-absorbing compound related to flavonoids.

\section{Materials and methods}

\section{Algal material}

U. penicilliformis (hereafter called Urospora in reference to this study) attached to boulders were collected in summer (July 2007) by hand during low tide beside the harbor in Ny Ålesund (Spitsbergen, $78^{\circ} 55^{\prime} \mathrm{N}, 11^{\circ} 56^{\prime} \mathrm{E}$; Fig. 1a, b). Filaments were carefully gleaned off several boulders and brought to the laboratory for microscopic identification (Fig. 1d, e).

\section{Radiation treatments}

White fluorescent tubes (Osram, L65 Watt/25S, Munich, Germany) and UVA-340 fluorescent tubes (Q-Panel, Cleveland, $\mathrm{OH}, \mathrm{USA}$ ) were used to provide photosynthetically active radiation (PAR, 400-700 $\mathrm{nm}$ ) and ultraviolet radiation (280-400 nm), respectively. To cut off different wavelength ranges from the spectrum emitted by the fluorescent tubes, cell culture dishes were covered with one of the following filters: Ultraphan transparent (Digefra $\mathrm{GmbH}$, Germany), Folanorm (Folex GmbH, Germany), or Ultraphan URUV farblos corresponding to the PAR + UVA + UV-B (PAB), PAR + UV-A (PA), and PAR (P) treatments, respectively. Field control (C) was a sample 
Fig. 1 Urospora penicilliformis habit (a, b), collection (c), and under microscope (d, e). Cells 90-100 $\mu \mathrm{m}$ in diameter
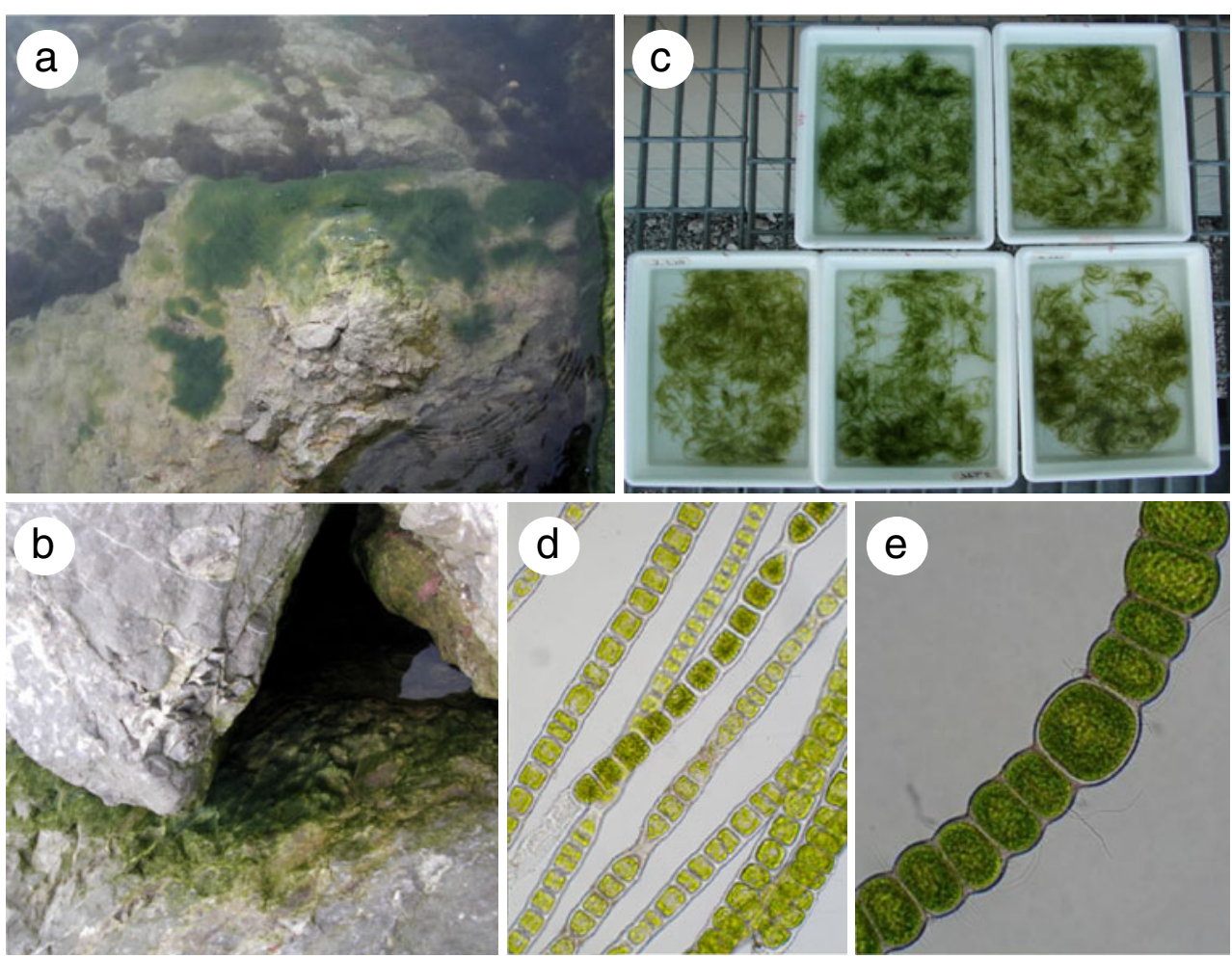

exposed to ambient solar radiation. Ultraviolet radiation was measured using a Solar Light PMA 2100 radiometer equipped with the UV-A sensor PMA 2110 and the UV-B Sensor PMA 2106 (Solar Light, Philadelphia, USA). Adjusted ultraviolet radiation below the cut-off filters was $4.34 \mathrm{~W} \mathrm{~m}^{-2}$ UV-A and $0.40 \mathrm{~W} \mathrm{~m}^{-2}$ UV-B. The available PAR measured using a cosine quantum sensor attached to a LI-COR data logger (LI-1000, LI-COR Biosciences, Lincoln, NE, USA) was $22 \mu \mathrm{mol}$ photons $\mathrm{m}^{-2} \mathrm{~s}^{-1}(\sim 4.73 \mathrm{~W}$ $\mathrm{m}^{-2}$ ). The PAR radiation at the sampling site was approximately $500-1,200 \mu \mathrm{mol}$ photons $\mathrm{m}^{-2} \mathrm{~s}^{-1}$. The maximum daily average irradiance in summer (June and July) is $790 \mu \mathrm{mol}$ photons $\mathrm{m}^{-2} \mathrm{~s}^{-1}$ PAR, $17 \mathrm{~W} \mathrm{~m}^{-2} \mathrm{UV}-\mathrm{A}$, and $0.30 \mathrm{~W} \mathrm{~m}^{-2}$ UV-B in air (cf. Hanelt et al. 2001).

\section{Chlorophyll fluorescence measurements}

Photosynthetic activity was determined by measuring the variable chlorophyll (Chl) fluorescence of PSII. Rapid photosynthesis (in terms of relative electron transport rate, rETR $=$ PFR $\left.\times \Delta F / F_{\mathrm{m}}{ }^{\prime}\right)$ versus irradiance $(E)$ curves $(P-E$ curve) of single filaments were measured in triplicates using a Water Pulse Amplitude Modulation fluorometer (WaterPAM) consisting of Emitter-Detector Unit Water-ED and PAM-Control Universal Control Unit connected to a PC operated with WinControl software (Heinz Walz GmbH, Effeltrich, Germany; Roleda et al. 2006). $F_{\mathrm{o}}$ was measured with a red measuring light pulse $\left(\sim 0.3 \mu \mathrm{mol}\right.$ photon $\mathrm{m}^{-2} \mathrm{~s}^{-1}$, $650 \mathrm{~nm}$ ), and $F_{\mathrm{m}}$ was determined with a 600 -ms completely saturating red light pulse $\left(\sim 2,750 \mu \mathrm{mol}\right.$ photons $\left.\mathrm{m}^{-2} \mathrm{~s}^{-1}\right)$. Low and high actinic light intensities making up 8-12 points $\left(4-341 \mu \mathrm{mol}\right.$ photons $\left.\mathrm{m}^{-2} \mathrm{~s}^{-1}\right)$ were used. The hyperbolic tangent model of Jassby and Platt (1976) was used to estimate $P-E$ curve parameters described as:

$\mathrm{rETR}=\mathrm{rETR}_{\max } * \tanh \left(\alpha * \mathrm{E}_{\mathrm{PAR}} * \mathrm{rETR}_{\max }{ }^{-1}\right)$

where $\mathrm{rETR}_{\max }$ is the maximum relative electron transport rate, tanh is the hyperbolic tangent function, $\alpha$ is the electron transport efficiency, and $E$ is the photon fluence rate of PAR. Curve fit was calculated with the Solver Module of MS-Excel using the least squares method comparing differences between measured and calculated data (Roleda et al. 2006). The saturation irradiance for electron transport $\left(E_{\mathrm{k}}\right)$ was calculated as the light intensity at which the initial slope of the curve $(\alpha)$ intercepts the horizontal asymptote $\left(\mathrm{rETR}_{\max }\right)$.

In the laboratory $\left(7^{\circ} \mathrm{C}\right)$, approximately $10 \mathrm{~g}$ wet weight of Urospora filaments was spread out evenly in culture dishes $(45 \mathrm{~mm} \times 10 \mathrm{~mm})$ immersed with filtered seawater and exposed under the lamps covered with respective filters representing the $\mathrm{P}, \mathrm{PA}$, and $\mathrm{PAB}$ treatments. Effective quantum yield $\left(\Delta F / F_{\mathrm{m}}{ }^{\prime}, n=5\right)$ was measured using a Diving PAM device (Walz, Effeltrich, Germany) at initial $(18: 00 \mathrm{~h})$, at $1,2,4,8$ and $16 \mathrm{~h}$ after the start of UV exposure $(19: 00,20: 00,22: 00,02: 00,10: 00 \mathrm{~h})$ and $4 \mathrm{~h}$ after the end of UV exposure (14:00 h). Additional samples were exposed outdoor (circa $7^{\circ} \mathrm{C}$ air temperature) to ambient 
polar day solar radiation. $\Delta F / F_{\mathrm{m}}{ }^{\prime}(n=5)$ was measured after $8 \mathrm{~h}$ full solar radiation $\left(\max =900 \mu \mathrm{mol}\right.$ photons $\mathrm{m}^{-2} \mathrm{~s}^{-1}$, $\min =200 \mu \mathrm{mol}$ photons $\mathrm{m}^{-2} \mathrm{~s}^{-1}$ ) and after $12 \mathrm{~h}$ under shade (ca. 100-200 $\mu \mathrm{mol}$ photons $\mathrm{m}^{-2} \mathrm{~s}^{-1}$ ).

Pigment determination

After $16 \mathrm{~h}$ exposure to artificial laboratory irradiance, the laboratory-treated filaments together with freshly collected algae acclimated to ambient solar radiation were blotted semi-dry and immersed in dimethylformamide. High performance liquid chromatography (HPLC) analysis of all plastid pigments and $\alpha$-tocopherol were essentially performed as described in Remias et al. (2005). The pigments were calculated on the basis of total Chla $a=1$. To verify for possible changes in the Chla pool, data were also calculated on the basis of total lutein, which belongs to the most stable thylakoid pigments (data not shown). As this additional comparison did not show any changes in Chla content, Chla as reference parameter was preferred.

\section{Flavonoid determinations}

Preparation of samples followed the above procedure for pigment analysis, but the extraction was done in methanol. Samples were analyzed for flavonoid patterns according to Lütz et al. (2008). This method is suitable for screening most flavonoids known in UV protection in higher plants and of some phenylpropane precursors.

Transmission electron microscopy and electron energy loss spectroscopy

For electron microscopy, freshly collected Urospora filaments (field control, C) and samples exposed to additional $16 \mathrm{~h}$ of artificial laboratory irradiance consisting of PAR (P), PAR + UV-A (PA), and PAR + UV-A + UV-B (PAB) were fixed in $2.5 \%$ glutaraldehyde buffered by a $1: 1$ mixture of $0.05 \mathrm{M}$ cacodylate buffer (pH7.2) and filtered seawater for $2 \mathrm{~h}$ at about $7-10^{\circ} \mathrm{C}$. After washing in buffer, post-fixation was done with $1 \% \mathrm{OsO}_{4}$ in $0.05 \mathrm{M}$ cacodylate buffer at $4^{\circ} \mathrm{C}$ overnight. Dehydration occurred in increasing ethanol steps ending up with propylene oxide. Urospora filaments were embedded in Agar Scientific low viscosity epoxy resin. Ultrathin sections were examined in a LEO 912 AB Omega transmission electron microscope (Zeiss, Oberkochen) operated at $80 \mathrm{kV}$ by using a $\mathrm{LaB}_{6}$ cathode.

For electron energy loss spectroscopy (EELS) measurements, sections of 40 to $50 \mathrm{~nm}$ thickness were mounted on uncoated narrow mesh grids. A $100-\mu \mathrm{m}$ spectrometer entrance aperture was used for defining the measurement area. EELS were acquired at a transmission electron microscope (TEM) magnification of 25,000 by using a spectrum magnification of 125 , illumination angles up to $1.6 \mathrm{mrad}$, and exposure times between 2 and $20 \mathrm{~s}$. For EELS analyses, the TEM was operated at $120 \mathrm{kV}$. Micrographs and EELS were captured by a dual speed CCD Slow Scan Camera TRS Sharpeye (Troendle, Moorenwies, Germany) and were processed by use of ITEM Software (Olympus-SIS, Münster, Germany).

\section{Data analysis}

Empirical data were tested for Levene Statistics where homogeneity of variance was satisfied. Response variables ( $P-E$ curve parameter estimates, $\Delta F / F_{\mathrm{m}}{ }^{\prime}$, and pigments) were tested using analyses of variance (repeated measure analysis of variance, RMANOVA and one-way ANOVA; $P<0.05$ ) followed by Duncan's multiple range test (DMRT, $P<0.05)$. Statistical analyses were performed using SPSS software (Chicago, IL, USA).

\section{Results}

Vegetative and fertile gametophytic filaments of Urospora were observed (Fig. 1d, e). The smaller filaments are vegetative (Fig. 1d) while the broader filaments are composed of barrel-shaped cells, which will develop into zoosporangia (Fig. 1e).

$P-E$ curve parameters (Fig. 2, Table 1) showed significant treatment effect (ANOVA, $P<0.001$ ). The saturating irradiance $\left(E_{\mathrm{k}}\right)$, photosynthetic capacity in terms of $\mathrm{rETR}_{\max }$, and light-harvesting performance and photosynthetic conversion efficiency $(\alpha)$ in filaments exposed to low light (control) were higher compared to filaments exposed to the experimental radiation treatments (P, PA, and PAB). The UVRrelated decrease in the parameter estimates ranges $15-50 \%$, $54-81 \%$, and $46-61 \%$ for the $E_{\mathrm{k}}, \mathrm{rETR}_{\max }$, and $\alpha$, respectively, of which $41 \%\left(E_{\mathrm{k}}\right), 58 \%\left(\mathrm{rETR}_{\max }\right)$, and $28 \%$ $(\alpha)$ was due to the UV-B wavebands.

Time-series measurements of the effective quantum yield $\left(\Delta F / F_{\mathrm{m}}{ }^{\prime}\right.$, Fig. 3) showed a PAR dose-dependent (as a function of exposure time) decrease in the photosynthesis of Urospora. After exposure to $16 \mathrm{~h}$ of low PAR (control, $10 \mu \mathrm{mol}$ photons $\mathrm{m}^{-2} \mathrm{~s}^{-1}=5.76 \times 10^{2} \mathrm{~kJ} \mathrm{~m}^{-2}$ ) and $4 \mathrm{~h}$ of moderate PAR (P treatment, $22 \mu \mathrm{mol}$ photons $\mathrm{m}^{-2} \mathrm{~s}^{-1}=$ $\left.3.17 \times 10^{2} \mathrm{~kJ} \mathrm{~m}^{-2}\right)$, respectively, the $\Delta F / F_{\mathrm{m}}^{\prime}$ was not inhibited. Photoinhibition of PSII quantum yield under PAR was observed only after exposure to $8 \mathrm{~h}$ of moderate PAR (P treatment, $22 \mu \mathrm{mol}$ photons $\mathrm{m}^{-2} \mathrm{~s}^{-1}=6.34 \times 10^{2} \mathrm{~kJ}$ $\mathrm{m}^{-2}$ ) and a slight decrease in $\Delta F / F_{\mathrm{m}}{ }^{\prime}$ after $20 \mathrm{~h}$ exposure to low PAR (control, $10 \mu \mathrm{mol}$ photons $\mathrm{m}^{-2} \mathrm{~s}^{-1}=7.20 \times 10^{2} \mathrm{~kJ}$ $\mathrm{m}^{-2}$ ). Recovery of PSII was, however, observed when samples previously exposed to $16 \mathrm{~h}$ of high photon fluence rate (PFR) of PAR were transferred to low PFR of PAR. 


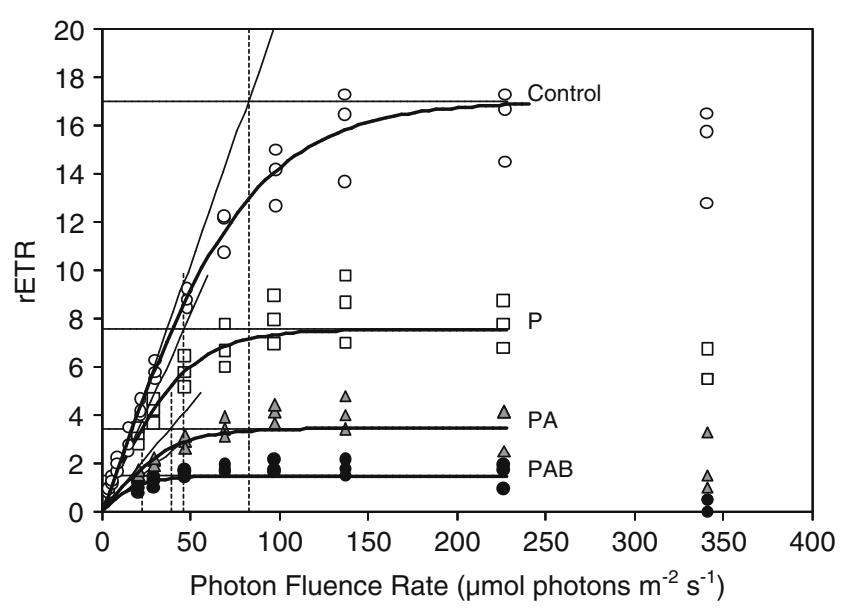

Fig. 2 Rapid light curves (photosynthesis-irradiance, $P-E$ curves) of Urospora penicilliformis filaments in control (empty circle) maintained under low white light $\left(10 \mu \mathrm{mol}\right.$ photons $\left.\mathrm{m}^{-2} \mathrm{~s}^{-1}\right)$, after $8 \mathrm{~h}$ exposure to photosynthetically active radiation (empty square, PAR only), PAR + UV-A (filled triangle), and PAR + UV-A + UV-B (filled circle). Artificial light photon flux density (PFD) is $22 \mu \mathrm{mol}$ photons $\mathrm{m}^{-2} \mathrm{~s}^{-1}$. PFR is the respective photon fluence rate of actinic light and rETR is the relative electron transport rate. Corresponding $P-E$ curve parameters are shown in Table 1

Exposure to PAR supplemented with UVR showed a decrease in $\Delta F / F_{\mathrm{m}}{ }^{\prime}$ to a maximum of $15-31 \%$ after $16 \mathrm{~h}$ in $\mathrm{PA}$ and PAB treatment relative to moderate PAR, respectively. Exposure to ambient solar radiation reduced the PSII quantum yield by $58 \%$ relative to $\mathrm{P}$ treatment. The higher irradiance of the ambient solar radiation contributed $31 \%$ reduction in $\Delta F / F_{\mathrm{m}}{ }^{\prime}$ compared to the lower irradiance of $\mathrm{PAB}$ treatment in the laboratory. When allowed to recover under low PFR of PAR in the laboratory, $\Delta F / F_{\mathrm{m}}{ }^{\prime}$ increased by $33-48 \%$ in PA and PAB-pretreated samples, respectively. Reduction of the PFR under shade condition was also observed to initiate photosynthetic recovery under natural solar radiation (Fig. 3). Repeated measure analysis of

Table 1 Photosynthesis-irradiance $(P-E)$ curve parameters $(n=3)$, corresponding to Fig. 2, estimated using the hyperbolic tangent model of Jassby and Platt (1976)

\begin{tabular}{lcrl}
\hline Treatment & $E_{\mathrm{k}}\left(\mu \mathrm{mol}\right.$ photons $\left.\mathrm{m}^{-2} \mathrm{~s}^{-1}\right)$ & $\mathrm{rETR}_{\max }$ & Alpha \\
\hline Control & $82^{\mathrm{a}}$ & $16.98^{\mathrm{a}}$ & $0.207^{\mathrm{a}}$ \\
P & $46^{\mathrm{b}}$ & $7.53^{\mathrm{b}}$ & $0.163^{\mathrm{b}}$ \\
PA & $39^{\mathrm{b}}$ & $3.43^{\mathrm{c}}$ & $0.088^{\mathrm{c}}$ \\
PAB & $23^{\mathrm{c}}$ & $1.45^{\mathrm{d}}$ & $0.063^{\mathrm{c}}$ \\
\hline
\end{tabular}

Saturating irradiance $\left(E_{\mathrm{k}}\right)$ is the light intensity at which the initial slope of the curve $(\alpha)$ intercepts the horizontal asymptote, the maximum relative electron transport rate $\left(\mathrm{rETR}_{\max }\right)$. Analysis of variance (ANOVA, $P<0.001$ ) showed significant difference between radiation treatments. Letters show result of post hoc Duncan's multiple range tests $(P<0.05)$; different letters refer to significant differences between mean values

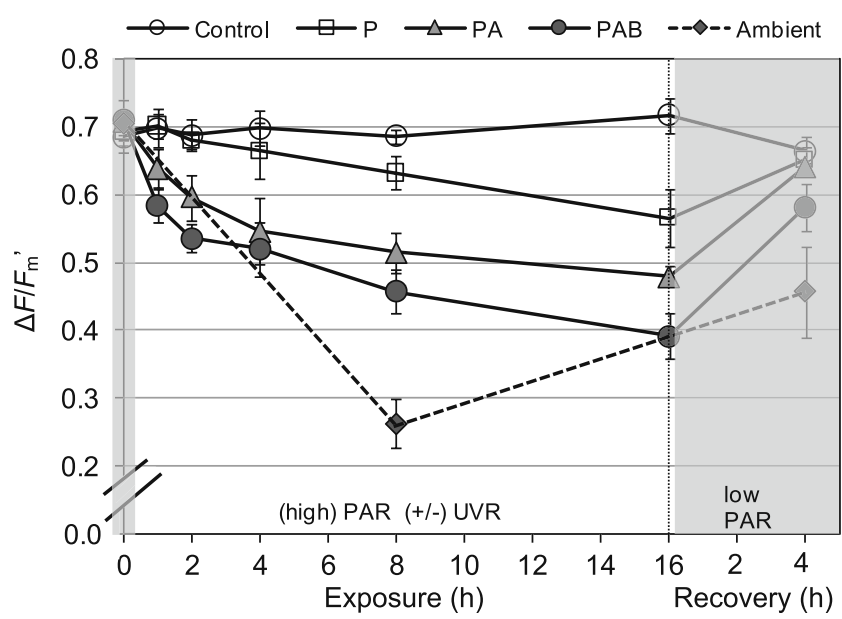

Fig. 3 Time-series mean effective quantum yield $\left(\Delta F / F_{\mathrm{m}}{ }^{\prime}\right)$ of Urospora penicilliformis filaments exposed to artificial and ambient polar day solar radiation. Light treatment consists of photosynthetically active radiation $(\mathrm{PAR}=\mathrm{P}), \mathrm{PAR}+\mathrm{UV}-\mathrm{A}(\mathrm{PA})$ and $\mathrm{PAR}+\mathrm{UV}-\mathrm{A}+$ UV-B (PAB). Artificial light photon flux density (PFD) is $22 \mu \mathrm{mol}$ photons $\mathrm{m}^{-2} \mathrm{~s}^{-1}$. Low PAR (gray shade) during $4 \mathrm{~h}$ of recovery is 10 and $200 \mu \mathrm{mol}$ photons $\mathrm{m}^{-2} \mathrm{~s}^{-1}$ under laboratory and ambient conditions, respectively. $\Delta F / F_{\mathrm{m}}{ }^{\prime}$ at initial (time zero) and in control were maintained and measured under laboratory low PAR condition. Vertical bars are standard deviations (SD, $n=5)$

variance (RMANOVA, $P<0.05$ ) showed significant difference between treatments. Post hoc DMRT $(P=0.05)$ showed $\Delta F / F_{\mathrm{m}}{ }^{\prime}$ in control $>\mathrm{P}>\mathrm{PA}>\mathrm{PAB}>$ ambient.

The pigments observed in the HPLC chromatogram (Fig. 4) showed a typical composition similar to higher plants and other green algae (Lütz et al. 1997; Larkum et al. 2003). All pigments (chlorophylls, xanthophylls, carotenes, and the antioxidant $\alpha$-tocopherol) as well as the Chla/b and $\mathrm{Chl} / \mathrm{Car}$ ratios were not significantly different between treatments and field collected samples (Table 2), except for the lower neoxanthin and higher antheraxanthin contents in field collected samples (one-way ANOVA, $P=0.05$ ) compared to samples exposed to extra irradiation treatments in the laboratory. HPLC separations of pigments showed the appearance (in the range of $2.6-9.8 \%$ of the HPLC peak area of Chla) of a possible break-down product (with spectral similarity to protochlorophyll) in samples exposed to additional laboratory radiation treatment.

An HPLC analysis system for a number of typical UVshielding flavonoids and some of their phenylpropane precursors (Lütz et al. 2008) showed the absence of any such flavonoids in Urospora. We were not able to screen for MAAs, but according to the literature (Larkum et al. 2003), their occurrence in green algae is not yet proven.

Fine structure analysis showed that the filaments were surrounded by extraordinary thick longitudinal cell walls with a thickness of about 4-6 $\mu \mathrm{m}$. The outermost cell wall layer had a looser, less compact appearance than the inner layer indicating its mucous nature. It was covered by 
Fig. 4 HPLC chromatogram showing typical photosynthetic pigments in Urospora penicilliformis and additional chlorophyll-derivative peak (arrow) similar to protochlorophyll

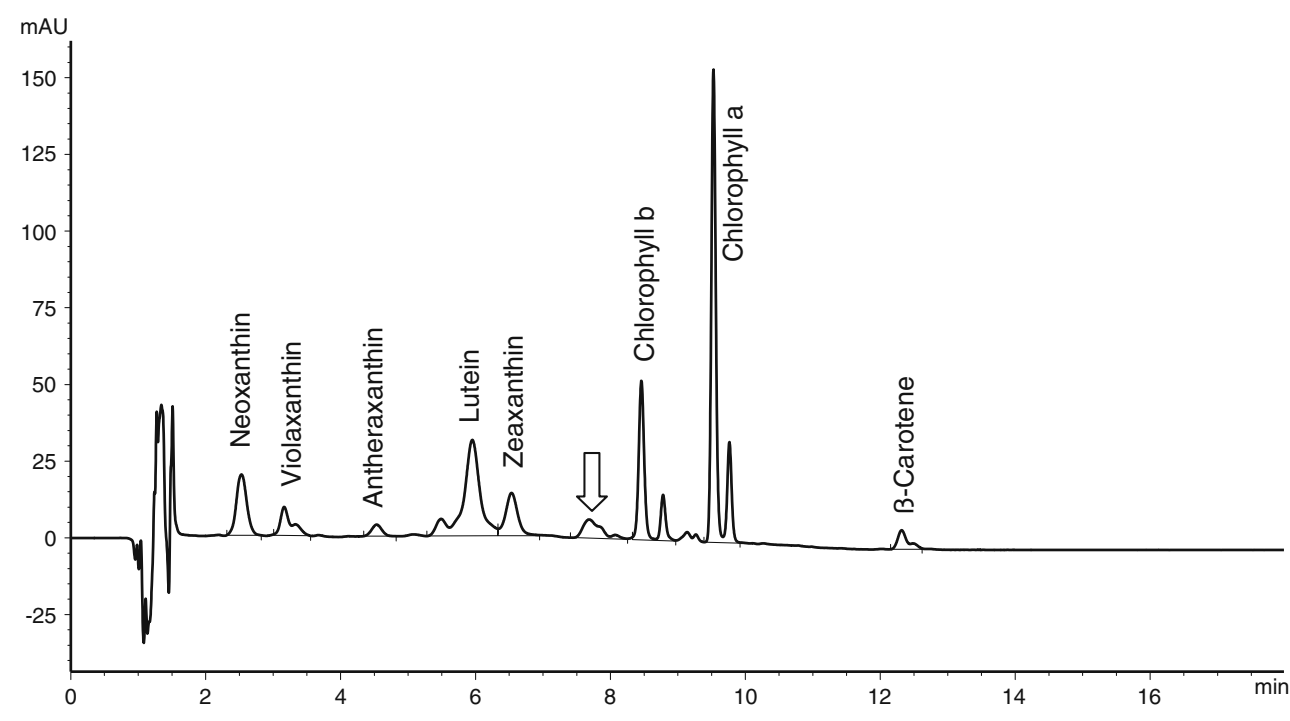

Urospora filaments to those after experimental $\mathrm{P}, \mathrm{PA}$, and PAB exposure did not reveal any significant differences (Figs. 5d, 7a-d). Whereas the ultrastructure and morphology, particularly of the chloroplast and mitochondria, were unchanged, a slight increase in the number of electron dense bodies in the cytoplasm can be observed both after PAR and UVR.

\section{Discussion}

The result of our study showed that Arctic Urospora inhabiting the upper shoreline is resilient to ambient and artificial UVR and showed no significant long-term negative impact on their photophysiology and ultrastructure. In the absence of UV-shielding flavonoids and some

Table 2 Photosynthetic pigments and $\alpha$-tocopherol in Urospora penicilliformis expressed as ratio to Chla [w/w]

\begin{tabular}{|c|c|c|c|c|c|c|c|c|c|c|c|c|c|}
\hline \multirow[t]{2}{*}{ Sample ID } & \multicolumn{13}{|c|}{ Pigments (ratio to Chla $[w / w]$ ) } \\
\hline & Neo & Vio & Ant & Lut & Zea & Chl $b$ & Chla & bcar & aToc & Chla/b & Car & X-pig & $\mathrm{Chl} / \mathrm{Car}$ \\
\hline $\mathrm{C}$ & 0.055 & 0.047 & 0.032 & 0.167 & 0.052 & 0.402 & 1.000 & 0.033 & 0.005 & 2.504 & 0.383 & 0.130 & 3.691 \\
\hline SD & 0.001 & 0.008 & 0.008 & 0.021 & 0.022 & 0.044 & 0.000 & 0.002 & 0.001 & 0.272 & 0.045 & 0.021 & 0.545 \\
\hline $\mathrm{P}$ & 0.070 & 0.041 & 0.019 & 0.183 & 0.061 & 0.399 & 1.000 & 0.025 & 0.003 & 2.521 & 0.399 & 0.121 & 3.534 \\
\hline SD & 0.006 & 0.005 & 0.004 & 0.016 & 0.010 & 0.036 & 0.000 & 0.008 & 0.002 & 0.245 & 0.034 & 0.015 & 0.386 \\
\hline PA & 0.071 & 0.042 & 0.021 & 0.186 & 0.064 & 0.410 & 1.000 & 0.028 & 0.004 & 2.449 & 0.412 & 0.127 & 3.450 \\
\hline SD & 0.003 & 0.006 & 0.006 & 0.018 & 0.010 & 0.033 & 0.000 & 0.008 & 0.003 & 0.204 & 0.036 & 0.020 & 0.389 \\
\hline PAB & 0.069 & 0.046 & 0.021 & 0.178 & 0.057 & 0.422 & 1.000 & 0.028 & 0.005 & 2.375 & 0.397 & 0.123 & 3.590 \\
\hline SD & 0.005 & 0.005 & 0.004 & 0.015 & 0.008 & 0.017 & 0.000 & 0.008 & 0.001 & 0.097 & 0.023 & 0.013 & 0.249 \\
\hline
\end{tabular}

Pigments measured are chlorophylls (Chla set to 1, and Chlb), total carotenoids (car), $\alpha$-tocopherol (aToc), and xanthophyll pigments (X-pig) consisting of neoxanthin (Neo), violaxanthin (Vio), antheraxanthin (Ant), lutein (Lut), zeaxanthin (Zea), and $\beta$-carotene (bcar). X-pig: sum of xanthophyll cycle pigments. Sample IDs are: $\mathrm{C}=$ freshly collected algae acclimated to ambient solar radiation; P, PA, and PAB were filaments exposed to additional $16 \mathrm{~h}$ of artificial laboratory radiation consisting of photosynthetically active radiation (PAR only), PAR + UV-A, and PAR + UV-A + UV-B, respectively. Data are means of mostly five individual samples and HPLC assays. Pigment concentrations showed no significant difference between treatments 
Fig. 5 a-c Ultrastructural details of untreated (field control) Urospora filaments. d Cortical cell region after PAR. $C W$ cell wall, $C h l$ chloroplast, $D$ dictyosome, $M$ mitochondrion, $N$ nucleus, st starch grain. Asterisks mark electron dense bodies in cytoplasm; arrow points at mineral deposition at cell surface
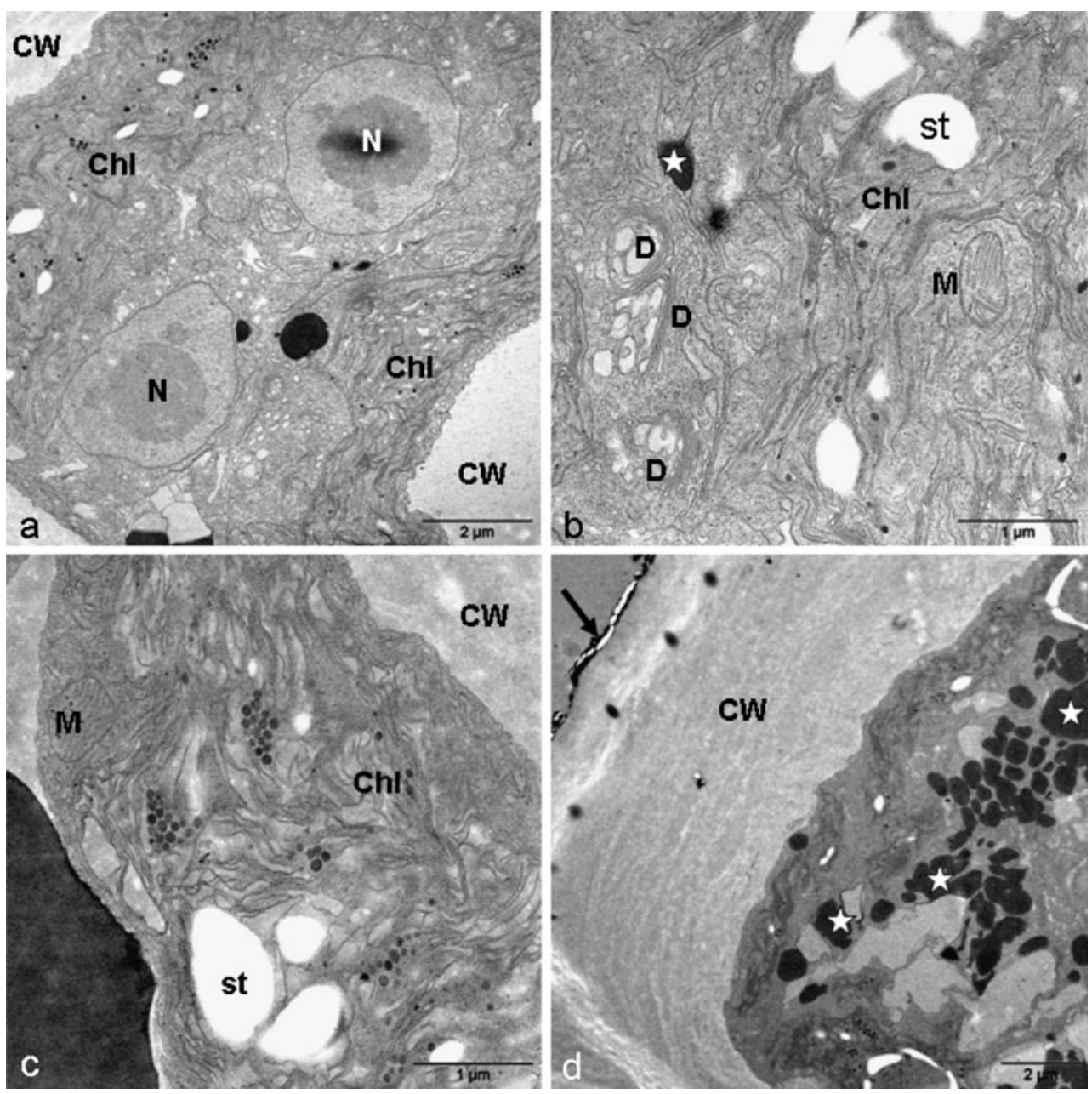

of their phenylpropane precursors, the mechanism of UV stress tolerance and/or resistance in this eulittoral green turf alga, periodically exposed to multiple stresses (i.e., high PAR and UVR, elevated temperature, osmotic stress, and desiccation), is yet unclear and needs further study.

Photoinhibition of PSII quantum yield in Urospora occurs under light exceeding their photosynthetic capacity. The reduction in $\Delta F / F_{\mathrm{m}}{ }^{\prime}$ under PAR treatment was not solely due to the photon fluence rate $(E=22 \mu \mathrm{mol}$ photons $\left.\mathrm{m}^{-2} \mathrm{~s}^{-1}\right)$, which was lower than the extrapolated $E_{\mathrm{k}}(46-82$ $\mu$ mol photons $\mathrm{m}^{-2} \mathrm{~s}^{-1}$ ), but rather due to long irradiation period, i.e., the total fluence of PAR applied $(H=$ fluence rate $\times$ exposure time in seconds, expressed in Joules per square meter). In vivo photoinhibition, however, provides an important protective function by suppressing electron transport and by inducing the formation of photochemically inactive reaction centers in the PSII, in which light energy is transformed into heat energy (Barber and Andersson 1992; Kreslavski et al. 2007).

On the other hand, UVR cannot be regarded as an "excessive energy input" in a proper sense. Its maximal irradiance is much smaller than that of PAR, and the UV wavebands do not contribute significant energy supply for photosynthetic chemistry. Among shallow water tropical macrophytes exposed to ambient solar radiation, the degree of photosynthetic photoinhibition $\left(F_{\mathrm{v}} / F_{\mathrm{m}}\right)$ was lowest in samples exposed to UV-only treatment compared to samples exposed to PAR + UV-A (PA) and PAR + UV-A + UV-B (PAB; Hanelt and Roleda 2009). Generally, UV has a direct adverse effect on photosynthesis. The UV-B inhibition spectrum corresponds much more with the spectral absorption by DNA and proteins rather than with photosynthetic pigments (Jones and Kok 1966). Consequently, numerous studies have shown that recovery from photoinhibition is delayed after exposure to additional UV-B irradiation (e.g., Häder and Figueroa 1997; Roleda et al. 2006).

Persistence of photoinhibition (chronic photoinhibition, cf. Osmond 1994) usually results from the imbalance between photodamage and repair of the photodamaged PSII (e.g., degradation and resynthesis of the key protein, D1, of the PSII). Therefore, the dynamic recovery of PSII function in Urospora may be attributed to the fast turnover of D1 protein (cf. Melis 1999). The same fast and reversible photosynthetic recovery was observed in an Antarctic 
Fig. 6 a-d EELS measured at mineral depositions covering the cell surface of Urospora penicilliformis. a Al-K edge, b $\mathrm{Si}-\mathrm{K}$ edge, c Fe-L3 edge, red spectrum measured in mineral deposition, green line control measured in cytoplasm, $\mathbf{d} \mathrm{O}-\mathrm{K}$ edge
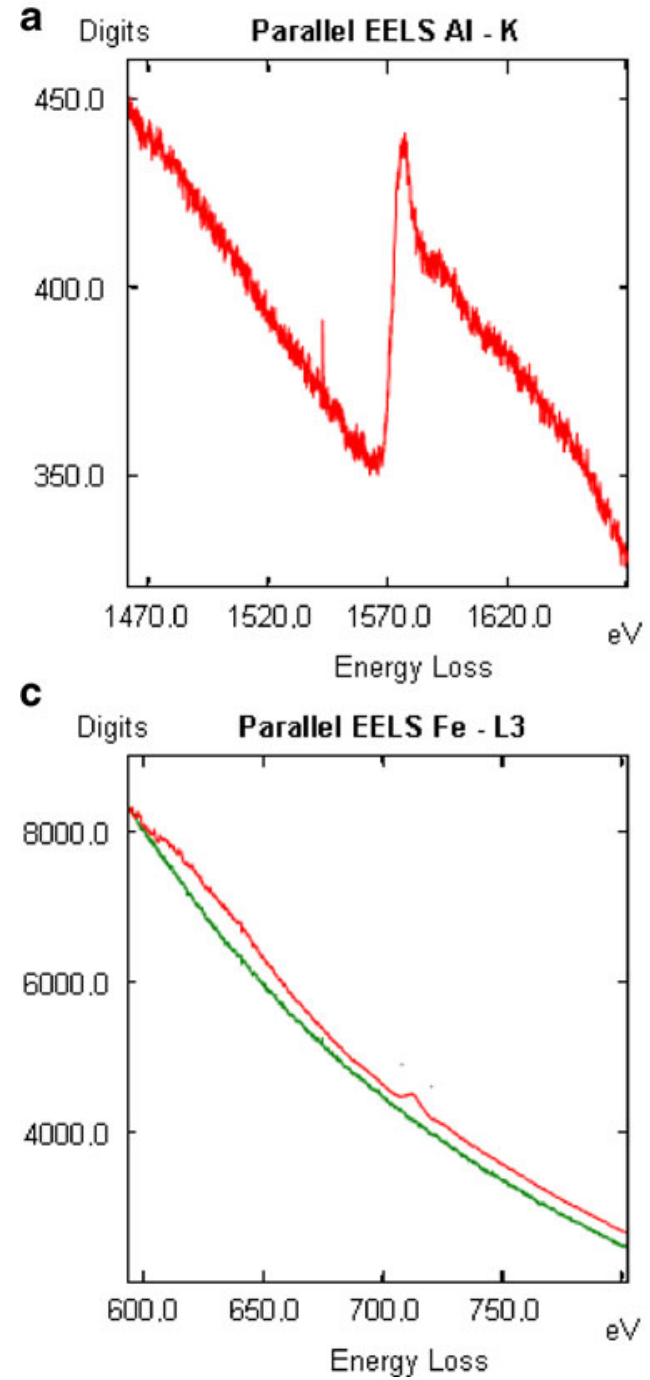
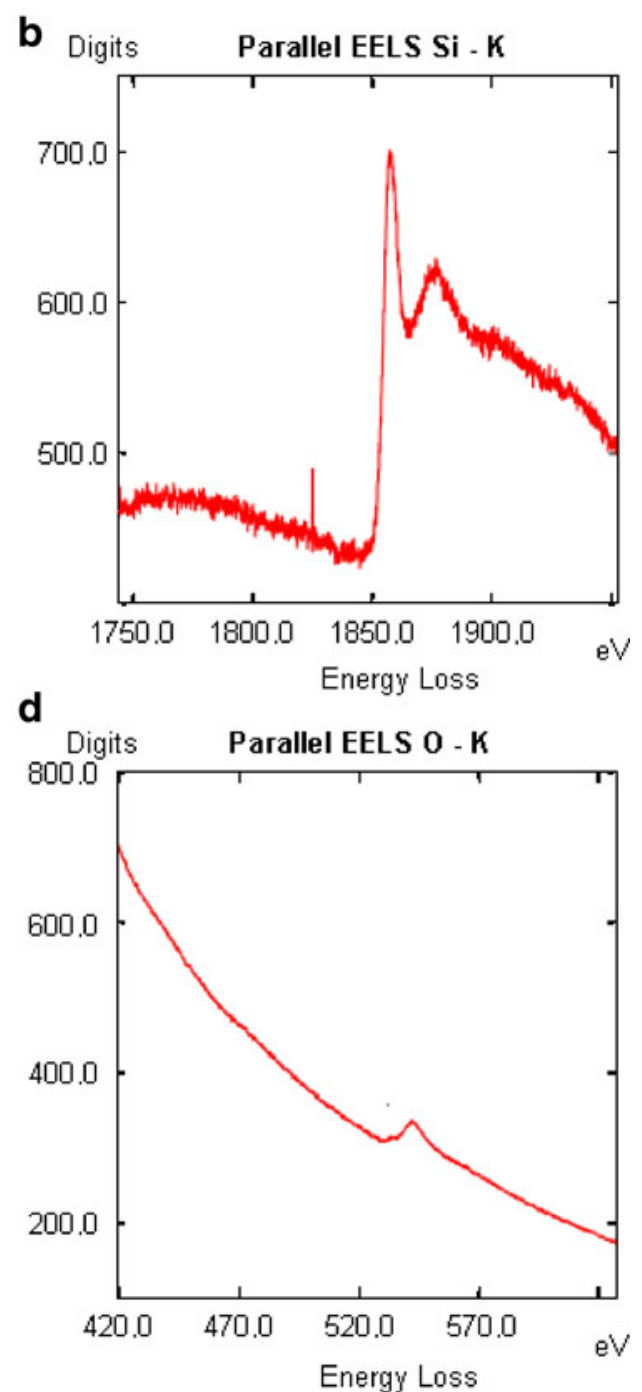

population of $U$. penicilliformis (Roleda et al. 2009). In some microalgae, the UV-B tolerance of the photosynthetic apparatus is associated with a strong capacity for recovery from UV-B-induced damage related to the D1 turnovermediated repair cycle (Xiong 2001). Protein repair capacity is also enhanced when UV-B is accompanied by lowintensity-visible light which also provides protection against photodamage (Sicora et al. 2003).

Photosynthetic electron transport yields a variety of reactive oxygen species (ROS; e.g., singlet oxygen, superoxide radicals $\left(\mathrm{O}_{2}{ }^{-}\right)$, and $\mathrm{H}_{2} \mathrm{O}_{2}$ radicals). Under excess light and UVR, the rate of ROS production increases appreciable. An increase in pigment content (carotenoids) in the presence of UV-B indicates an efficient protective pigment mechanism in Ulva rigida C. Agardh (Altamirano et al. 2000). Similarly, in Cladophora glomerata (Linnaeus) Kützing defense against UVR-induced oxidative stress is enabled through carotenoid protection including high carotenoids/chlorophyll ratio and a functional xanthophyll cycle (Choo et al. 2005). In comparison to the field control, lutein and neoxanthin of Urospora (this study) increased slightly, but only as a response to the lab conditions, because this increase also occurred in the PAR-only sample. A small and expected reduction in the sum of the xanthophyll cycle pigments indicates the lower PAR intensity in lab vs. the field. There is no treatment effect visible in these pigments. In the green alga Micrasterias denticulata Brébisson ex Ralfs, Lütz et al. (1997) also described very similar stabilities of the pigments under a much stronger PAR $\left(600 \mu \mathrm{mol}\right.$ photons $\left.\mathrm{m}^{-2} \mathrm{~s}^{-1}\right)$ and UV-B $\left(4.9 \mathrm{~W} \mathrm{~m}^{-2}\right.$ ) and UV-A (about $24 \mathrm{~W} \mathrm{~m}^{-2}$ ) exposure. This response was not observed in filamentous gametophyte (this study) and in propagules (zoospores and gametes; Roleda et al. 2009) of Urospora. Other defense mechanism against UVR-induced oxidative stress includes increase in superoxide dismutase activities reported in several green algae belonging to the genera Chaetomorpha, Cladophora, and Ulva (e.g., Choo et al. 2004; Bischof et al. 2006). Other targets which may reduce photosynthetic efficiency under UVR and high PAR include the ribulose-1,5-bisphosphate 
Fig. 7 a-d Ultrastructural details after UV exposure. a, b $\mathrm{PA} ; \mathbf{c}$, d PAB. Organelle distribution and morphology remain unchanged when compared to controls. $c C W$ cross cell wall, $C h l$ chloroplast, $M$ mitochondrion, $M V$ mucilage vesicles, $P$ pyrenoid, st starch grain. Asterisks mark electron dense cytoplasmic bodies
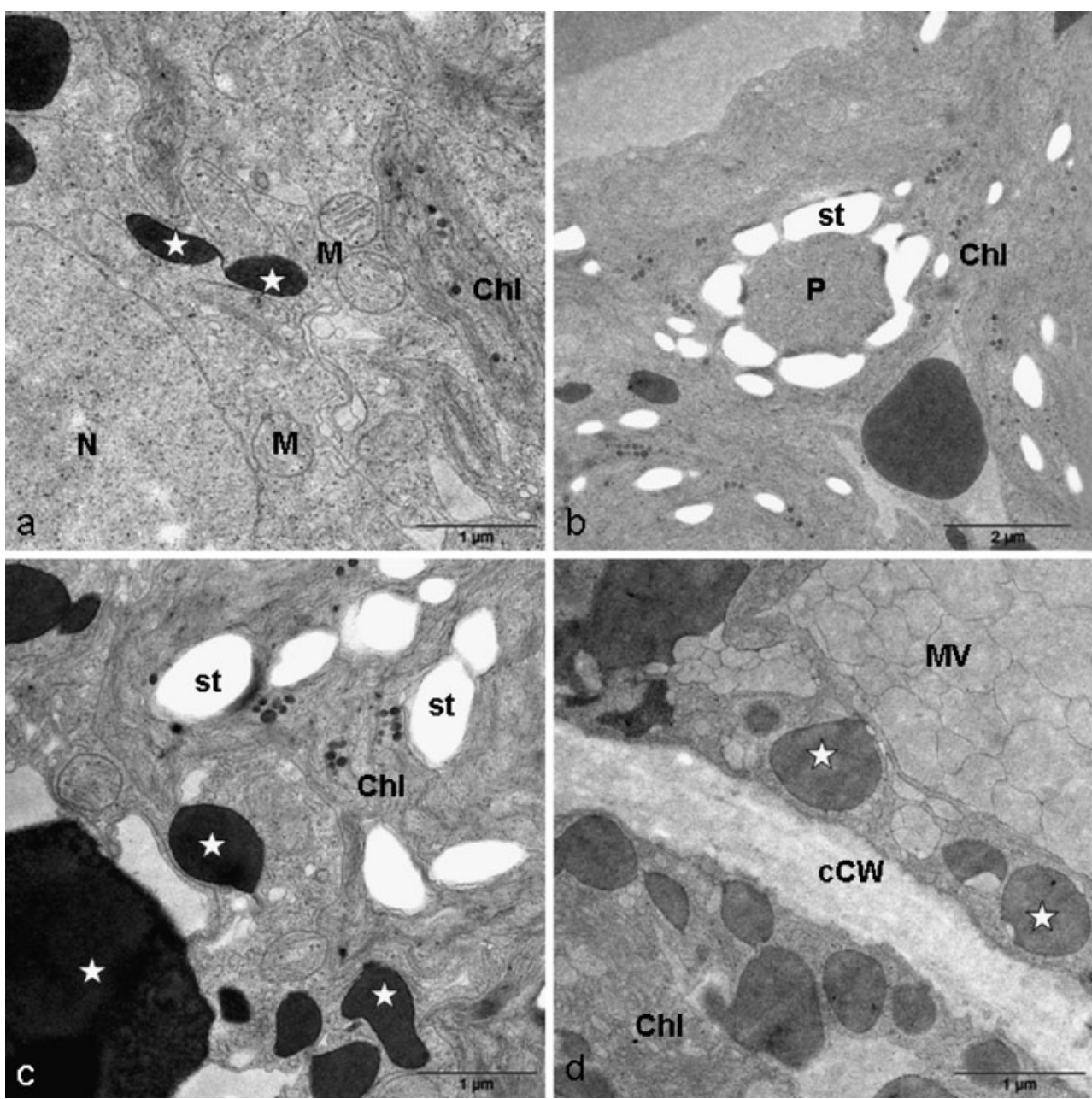

carboxylase-oxygenase (Rubisco), and structural chloroplast lipids (glycolipids and phosphatidylglycerol; Bischof et al. 2002a; Khotimchenko and Yakovleva 2004).

The appearance of a break-down product identified by diode array analysis as a derivative of chlorophyll in samples exposed to additional laboratory radiation treatment was similar to those observed in the green alga $M$. denticulata (Lütz et al. 1997). However, in Micrasterias cells, much severe PAR and UV exposure conditions were required to form this compound. The presence or inclusion of senescing cells in the field material may be responsible for its occurrence. The significance of this phenomenon is, however, unknown.

Although $\alpha$-tocopherol (vitamin E) is a well-known and important antioxidant within the plastids, the concentration was, however, rather low but the samples contain instead a considerable $\beta$-carotene content. Both antioxidants act as a tandem in radical defense (Palozza and Krinsky 1992; Fryer 1992) and should therefore be able to provide protection against oxidative stress in Urospora. In snow algae, alleviation against light stress is regulated by the accumulation of secondary carotenoids rather than by increased $\alpha$ - tocopherol synthesis (Remias et al. 2005). In Urospora, no significant difference in carotenoids and xanthophyll cycle pigments was observed between field-collected material and samples exposed to additional laboratory radiation treatments. Despite the experimental limitation to simulate the $\mathrm{PAR} / \mathrm{UV}$ ratios as in the field (which would require a very difficult technical setup), the relatively higher input of short wave irradiation to PAR (high UVR/PAR ratio) applied in the laboratory measured lower photoinhibition of PSII compared to ambient radiation (after $8 \mathrm{~h}$ of exposure, Fig. 3). This indicates that the photoprotective mechanism in Urospora seems to be already well-adjusted to their growth conditions exposed to high PAR and shows enough plasticity to cope with additional loads of short-wave irradiation.

Among macroalgal thalli, ultrastructural alteration was mostly investigated among rhodophytes which inhabit the sublittoral zone and therefore react more sensitively to UVR treatment. Palmaria decipiens (Reinsch) R.W. Ricker, Palmaria palmata (Linnaeus) Kuntze, Phycodrys austrogeorgica Skottsberg, Bangia atropurpurea (Roth) C. Agardh, and Odonthalia dentata (Linnaeus) Lyngbye exposed to UVR showed striking effects on the fine 
structure of their chloroplasts (Poppe et al. 2002, 2003; Holzinger et al. 2004). For example, the intrathylakoidal space was enlarged and the thylakoid membranes became wrinkled. Under enhanced UVR exposure, the thylakoids became tubular or disintegrated into "inside-out" vesicles in UVR-sensitive species (e.g., B. atropurpurea, Poppe et al. 2003). UVR can further induce formation of protrusions of the chloroplast envelope observed in P. palmata and $O$. dentata (Holzinger et al. 2004) or a disintegration of both envelope membranes as shown in P. austrogeorgica (Poppe et al. 2003). Protein crystals in the cytoplasm of $P$. austrogeorgica were also observed to be corroded after UVR treatment indicating either damage or remobilization of the stored protein necessary for repair processes (Poppe et al. 2003). Furthermore, UVR impact includes swelling of the cristae within the mitochondria and their transformation into sacculi (Poppe et al. 2002; Holzinger et al. 2004).

In the early life history stages of brown macroalgae, UVR-exposed zoospores of Laminaria hyperborea (Gunnerus) Foslie showed an enhanced formation of plastoglobuli in the chloroplast, mottling of the nucleoplasma, and transformation of the mitochondria structure from the tubulus to the sacculus type (Steinhoff et al. 2008).

In contrast, no significant UVR-induced alteration in fine structure of the supralittoral green alga $P$. crispa could be observed (Holzinger et al. 2006). Under enhanced UVR exposure, only slight alterations appeared within the chloroplasts, such as dilatations of thylakoids and a reduced number of plastoglobuli. Furthermore, the mitochondria showed slight alteration and cytoplasmic globules increased in size and became more abundant. These alterations are insignificant compared to those identified among the red algae. In the unicellular green alga $M$. denticulata, ultrastructural changes particularly of the endomembrane system appear at 280 and $275 \mathrm{~nm}$ cut-off wavelengths (Meindl and Lütz 1996). Morphological changes of dictyosomes, decrease in cisternal number, and reduced vesicle production were observed. In contrast, the unchanged ultrastructure observed in Urospora after PAR/UVR exposure in this study suggests that this green macroalga is well acclimated to such radiation conditions at upper eulittoral-supralittoral zones and is thus relatively robust and tolerant to UV stress.

Low UV-B-induced DNA damage and efficient DNA damage repair mechanism is reported in Antarctic $U$. penicilliformis (Roleda et al. 2009). In the absence of flavonoid-derivative substances in Urospora, other novel compounds and/or specific molecular or physical mechanisms might be responsible for their UVR tolerance. For example, epidermal localization of UVR screening compounds has been reported to provide UV-B protection in higher plants (Caldwell et al. 1998; Björn et al. 1999; Bilger et al. 2001; Nybakken et al. 2004). Mucilage or slime production may also protect algae against UVR (Meindl and
Lütz 1996; Ehling-Schulz et al. 1997). In comparison, we found that the cell walls of Urospora filaments were extremely thick, had a protective mucilage sheath, and were covered by a dense layer of mineral depositions (see also Lokhorst and Trask 1981). The architecture of this external envelope may provide a shield against unfavorable environmental conditions in general and against UVR in particular. Whether an active UV-screening substance is localized on the cell wall of Urospora is unknown.

Another aspect of ecological success of green turf algae, exposed to stressful environment, is by following a life history characteristic of $r$-strategies having high reproductive capacity, short generation time, and high growth rate and dispersal ability of propagules (zoospores and gametes). Moreover, algal turfs create a sharp irradiance gradient within the dense thalli and can self shade the understory portion. A microscale variation in pigment concentrations (Beach and Smith 1996a) and photosynthetic performance (Beach and Smith 1996b) between tissues from the canopy and understory microsites is reported among tropical intertidal turf-forming red macroalgae. The protective function of self-shading is also reported in Ulva and Chaetomorpha forming multilayers of floating mats during algal blooms (Bischof et al. 2002b, 2006).

Acclimation to high PAR and UVR levels, especially in tropical regions, is essential for stress resistance and persistence of intertidal algae (Beach and Smith 1996a, b; Hanelt and Roleda 2009). Despite some "beneficial" role of desiccation reported in several physiological studies (Hunt and Denny 2008, and references therein), it is always associated to only cause disruptive effects by most intertidal ecologists. The cost and benefit of desiccation coupled with other environmental stress factors (e.g., high PAR and UVR) should therefore be examined more closely to understand the resilience of intertidal algae in comparison to subtidal species. For instance, the ability of the bloomforming Ulva intestinalis Linnaeus (previously Enteromorpha intestinalis) to physiologically adapt to dynamic changes in salinity, nutrient, and light is responsible for their ecological success (Cohen and Fong 2004).

Acknowledgments This study is supported by the AWI and performed at the International Arctic Environmental Research and Monitoring Facility at Ny Ålesund, Svalbard. We thank Mrs. Maria Blassnigg for expert technical assistance with the HPLC analyses, Ancuela Andosch for preparing the ultrathin sections, and the ARCFAC 026129-50 project support to C.L. and U. L.-M. to work in Ny-Ålesund.

\section{References}

Altamirano M, Flores-Moya A, Figueroa F-L (2000) Long-term effects of natural sunlight under various ultraviolet radiation 
conditions on growth and photosynthesis of intertidal Ulva rigida (Chlorophyceae) cultivated in situ. Bot Mar 43:119-126. doi:10.1515/BOT.2000.012

Barber J, Andersson B (1992) Too much of a good thing: Light can be bad for photosynthesis. Trends Biochem Sci 17:61-66. doi: S1011-1344(98)/0968-0004(92) 90503-2

Beach KS, Smith CM (1996a) Ecophysiology of tropical rhodophytes. 1. Microscale acclimation in pigmentation. J Phycol 32:701-710. doi:10.1111/j.0022-3646.1996.00701.x

Beach KS, Smith CM (1996b) Ecophysiology of tropical rhodophytes. 2. Microscale acclimation in photosynthesis. J Phycol 32:710 718. doi:10.1111/j.0022-3646.1996.00710.x

Bilger W, Johnsen T, Schreiber U (2001) UV-excited chlorophyll fluorescence as a tool for the assessment of UV-protection by the epidermis of plants. J Exp Bot 52:2007-2014. doi:10.1093/jexbot/ 52.363 .2007

Bischoff B, Wiencke C (1995) Temperature adaption in strains of the amphi-equatorial green alga Urospora penicilliformis (Acrosiphoniales) biogeographical implications. Mar Biol (Berl) 122:681-688. doi:10.1007/BF00350690

Bischof K, Kräbs G, Wiencke C, Hanelt D (2002a) Solar ultraviolet radiation affects the activity of ribulose-1, 5-biphosphate carboxylase-oxygenase and the composition of photosynthetic and xanthophyll cycle pigments in the intertidal green alga Ulva lactuca L. Planta 215:502-509. doi:10.1007/s00425-002-0774-9

Bischof K, Peralta G, Kräbs G, van de Poll WH, Perez-Llorens JL, Breeman AM (2002b) Effects of solar UV-B radiation on canopy structure of Ulva communities from southern Spain. J Exp Bot 53:2411-2421. doi:10.1093/jxb/erf091

Bischof K, Rautenberger R, Brey L, Pérez-Lloréns JL (2006) Physiological acclimation to gradients of solar irradiance within mats of the filamentous green macroalga Chaetomorpha linum from southern Spain. Mar Ecol Prog Ser 306:165-175. doi:10.3354/meps306165

Björn LO, Callaghan TV, Gehrke C, Johanson U, Sonesson M (1999) Ozone depletion, ultraviolet radiation and plant life. Chemosphere, Glob Chang Sci 1:449-454. doi:S1011-1344(98)/S1465-9972(99)00038-0

Caldwell MM, Björn LO, Bornman JF, Flint SD, Kulandaivelu G, Teramura AH, Tevini M (1998) Effects of increased solar ultraviolet radiation on terrestrial ecosystems. J Photochem Photobiol 46:40-52. doi:10.1016/S1011-1344(98) 00184-5

Choo KS, Snoeijs P, Pedersen M (2004) Oxidative stress tolerance in the filamentous green algae Cladophora glomerata and Enteromorpha ahlneriana. J Exp Mar Biol Ecol 298:111-123. doi:10.1016/j.jembe.2003.08.007

Choo KS, Nilsson J, Pedersén M, Snoeijs P (2005) Photosynthesis, carbon uptake and antioxidant defence in two coexisting filamentous green algae under different stress conditions. Mar Ecol Prog Ser 292:127-138. doi:10.3354/meps292127

Cohen RA, Fong P (2004) Physiological response of a bloom-forming green macroalga to short-term change in salinity, nutrients, and light help explain its ecological success. Estuaries 27:209-216. doi:10.1007/BF02803378

Davison IR, Pearson GA (1996) Stress tolerance in intertidal seaweeds. J Phycol 32:197-211. doi:10.1111/j.0022-3646.1996.00197.x

Ehling-Schulz M, Bilger W, Scherer S (1997) UV-B-induced synthesis of photoprotective pigments and extracellular polysaccharides in the terrestrial cyanobacterium Nostoc commune. J Bacteriol 179:1940-1945

Fryer MJ (1992) The antioxidant effects of thylakoid vitamin-E ( $\alpha$ tocopherol). Plant Cell Environ 15:381-392. doi:10.1111/j.13653040.1992.tb00988.x

Fukuda S, Zamakawa R, Hirai M, Kashino Y, Koike H (2008) Mechanisms to avoid photoinhibition in a desiccation-tolerant cyanobacterium, Nostoc commune. Plant Cell Physiol 49:488492. doi: $10.1093 / \mathrm{pcp} / \mathrm{pcn} 018$
Häder DP, Figueroa FL (1997) Photoecophysiology of marine macroalgae. Photochem Photobiol 66:1-14. doi:10.1111/j.17511097.1997.tb03132.x

Han Y-S, Han T (2005) UV-B induction of UV-B protection in Ulva pertusa (Chlorophyta). J Phycol 41:523-530. doi:10.1111/j.15298817.2005.00072.x

Hanelt D, Roleda MY (2009) UVB radiation may ameliorate photoinhibition in specific shallow-water tropical marine macrophytes. Aquat Bot. doi:10.1016/j.aquabot.2008.12.005

Hanelt D, Tüg H, Bischof K, Gro $\beta$ C, Lippert H, Sawall T, Wiencke C (2001) Light regime in an arctic fjord: a study related to stratospheric ozone depletion as a basis for determination of UV effects on algal growth. Mar Biol (Berl) 138:649-658. doi:10.1007/s002270000481

Holzinger A, Lütz C (2006) Algae and UV irradiation: effects on ultrastructure and related metabolic functions. Micron 37:190 207. doi:10.1016/j.micron.2005.10.015

Holzinger A, Lütz C, Karsten U, Wiencke C (2004) The effect of ultraviolet radiation on ultrastructure and photosynthesis in the red macroalgae Palmaria palmata and Odonthalia dentata from Arctic waters. Plant Biol 6:568-577. doi:10.1055/s-2004-821003

Holzinger A, Karsten U, Lütz C, Wiencke C (2006) Ultrastructure and photosynthesis in the supralittoral green macroalga Prasiola crispa from Spitsbergen (Norway) under UV exposure. Phycologia 45:168-177. doi:10.2216/05-20.1

Hunt LJH, Denny MW (2008) Desiccation protection and disruption: a trade-off for an intertidal marine alga. J Phycol 44:1164-1170. doi:10.1111/j.1529-8817.2008.00578.x

Jassby AD, Platt T (1976) Mathematical formulation of the relationship between photosynthesis and light for phytoplankton. Limnol Oceanogr 21:540-547

Jones LW, Kok B (1966) Photoinhibition of chloroplast reactions. I. Kinetics and action spectra. Plant Physiol 41:1037-1043. doi:10.1104/pp. 41.6.1037

Jordan BR (2002) Molecular response of plant cells to UV-B stress. Funct Plant Biol 29:909-916. doi:10.1071/FP02062

Karsten U, Friedl T, Schumann R, Hoyer K, Lembcke S (2005) Mycosporine-like amino acids and phylogenies in green algae: Prasiola and its relatives from the Trebouxiophyceae (Chlorophyta). J Phycol 41:557-566. doi:10.1111/j.1529-8817.2005.00081.x

Karsten U, Lembcke S, Schumann R (2007) The effects of ultraviolet radiation on photosynthetic performance, growth and sunscreen compounds in aeroterrestrial biofilm algae isolated from building facades. Planta 225:991-1000. doi:10.1007/s00425-006-0406-x

Khotimchenko SV, Yakovleva IM (2004) Effect of solar irradiance on lipids of the green alga Ulva fenestrata Postels et Ruprecht. Bot Mar 47:395-401. doi:10.1515/BOT.2004.050

Kremb SG (2007) UV-induzierte Veränderungen der Genexpression bei marinen Makroalgen. PhD dissertation, Technische Universität München, Germany, $161 \mathrm{pp}$.

Kreslavski VD, Carpentier R, Klimov VV, Murata N, Allakhverdiev SI (2007) Molecular mechanisms of stress resistance of the photosynthetic apparatus. Biol Membr 24:195-217

Larkum AWD, Douglas SE, Raven JA (2003) Photosynthesis in algae. Kluwer, Dordrecht, The Netherlands

Lokhorst GM, Trask BJ (1981) Taxonomic studies on Urospora (Acrosiphoniales, Chlorophyceae) in western Europe. Acta Bot Neerl 30:353-431

Lütz C, Seidlitz HK, Meindl U (1997) Physiological and structural changes in the chloroplast of the green alga Micrasterias denticulata induced by UV-B simulation. Plant Ecol 128:55-64. doi:10.1023/A:1009754722357

Lütz C, Blassnigg M, Remias D (2008) Different flavonoid patterns in Deschampsia antarctica and Colobanthus quitensis from the maritime Antarctic. Ber Polarforsch Meeresfrosch 571:192-199 
Meindl U, Lütz C (1996) Effects of UV irradiation on cell development and ultrastructure of the green alga Micrasterias. J Photochem Photobiol B 36:285-292. doi:10.1016/S1011-1344(96) 07395-2

Melis A (1999) Photosystem-II damage and repair cycle in chloroplast: what modulates the rate of photodamge in vivo? Trends Plant Sci 4:130-135. doi:10.1016/S1360-1385(99) 01387-4

Nybakken L, Bilger W, Johanson U, Björn LO, Zielke M, Solheim B (2004) Epidermal UV-screening in vascular plants from Svalbard (Norwegian Arctic). Polar Biol 27:383-390. doi:10.1007/s00300004-0602-8

Osmond CB (1994) What is photoinhibition? Some insights from comparisons of shade and sun plant. In: Baker NR, Bowyer JR (eds) Photoinhibition of photosynthesis from the molecular mechanisms to the field. BIOS Scientific, Oxford, pp 1-24

Palozza P, Krinsky NI (1992) $\beta$-Carotene and $\alpha$-tocopherol are synergistic antioxidants. Arch Biochem Biophys 297:184-187. doi:10.1016/0003-9861(92) 90658-J

Pérez-Rodríguez E, Aguilera J, Gómez I, Figueroa F-L (2001) Excretion of coumarins by the Mediterranean green alga Dasycladus vermicularis in response to environmental stress. Mar Biol (Berl) 139:633-639. doi:10.1007/s002270100588

Poppe F, Hanelt D, Wiencke C (2002) Changes in ultrastructure, photosynthetic activity and pigments in the Antarctic Red alga Palmaria decipiens during acclimation to UV radiation. Bot Mar 45:253-261. doi:10.1515/BOT.2002.024

Poppe F, Schmidt RAM, Hanelt D, Wiencke C (2003) Effects of UV radiation on the ultrastructure of several red algae. Phycol Res $51: 11-19$

Remias D, Lütz-Meindl U, Lütz C (2005) Photosynthesis, pigments and ultrastructure of the alpine snow alga Chlamydomonas nivalis. Eur J Phycol 40:259-268. doi:10.1080/09670260500202148
Roleda MY, Hanelt D, Wiencke C (2006) Exposure to ultraviolet radiation delays photosynthetic recovery in Arctic kelp zoospores. Photosynth Res 88:311-322. doi:10.1007/s11120-0069055-y

Roleda MY, Wiencke C, Hanelt D, Bischof K (2007) Sensitivity of the early life stages of macroalgae from the Northern Hemisphere to ultraviolet radiation. Photochem Photobiol 83:851-862

Roleda MY, Mohlin M, Pattanaik B, Wulff A (2008) Photosynthetic response of Nodularia spumigena to UV and photosynthetically active radiation depends on nutrient $(\mathrm{N}$ and $\mathrm{P})$ availability. FEMS Microbiol Ecol 66:230-242. doi:10.1111/j.15746941.2008.00572.x

Roleda MY, Campana G, Wiencke C, Hanelt D, Quartino ML, Wulff A (2009) Sensitivity of Antarctic Urospora penicilliformis (Ulotrichales, Chlorophyta) to ultraviolet radiation is life stage dependent. J Phycol 45:xxx-Xxx (in press)

Rozema J, van de Staaij J, Björn LO, Caldwell M (1997) UV-B as an environmental factor in plant life: stress and regulation. Trends Ecol Evol 12:22-28. doi:10.1016/S0169-5347(96) 10062-8

Sicora C, Máté Z, Vass I (2003) The interaction of visible and UV-B light during photodamage and repair of photosystem II. Photosynth Res 75:127-137. doi:10.1023/A:1022852631339

Steinhoff FS, Wiencke C, Müller R, Bischof K (2008) Effects of ultraviolet radiation and temperature on the ultrastructure of zoospores of the brown macroalga Laminaria hyperborea. Plant Biol 10:388-397. doi:10.1111/j.1438-8677.2008. 00049.x

Xiong F (2001) Evidence that UV-B tolerance of the photosynthetic apparatus in microalgae is related to the D1-turnover mediated repair cycle in vivo. J Plant Physiol 158:285-294. doi:10.1078/ 0176-1617-00306 